\title{
Evaluation of a Novel Calcium Channel Agonist for Therapeutic Potential in Lambert-Eaton Myasthenic Syndrome
}

\author{
Tyler B. Tarr, ${ }^{1}$ Waqas Malick, ${ }^{1}$ Mary Liang, ${ }^{2}$ Guillermo Valdomir, ${ }^{2}$ Michael Frasso, ${ }^{2}$ David Lacomis, ${ }^{3}$ \\ Stephen W. Reddel, ${ }^{5}$ Adolfo Garcia-Ocano, ${ }^{4}$ Peter Wipf, ${ }^{2}$ and Stephen D. Meriney ${ }^{1}$ \\ ${ }^{1}$ Department of Neuroscience, Center for Neuroscience, ${ }^{2}$ Department of Chemistry and Center for Chemical Methodologies and Library Development, \\ ${ }^{3}$ Departments of Neurology and Pathology, Division of Neuromuscular Diseases, ${ }^{4}$ Departments of Medicine, Cell Biology, and Physiology, University of \\ Pittsburgh, Pittsburgh, Pennsylvania 15261, and ${ }^{5}$ Department of Clinical Neurology, Concord Hospital, Sydney, NSW 2139, Australia
}

We developed a novel calcium $\left(\mathrm{Ca}^{2+}\right)$ channel agonist that is selective for $\mathrm{N}$ - and $\mathrm{P} / \mathrm{Q}-\mathrm{type} \mathrm{Ca}^{2+}$ channels, which are the $\mathrm{Ca}^{2+}$ channels that regulate transmitter release at most synapses. We have shown that this new molecule (GV-58) slows the deactivation of channels, resulting in a large increase in presynaptic $\mathrm{Ca}^{2+}$ entry during activity. GV-58 was developed as a modification of $(R)$-roscovitine, which was previously shown to be $\mathrm{Ca}^{2+}$ channel agonist, in addition to its known cyclin-dependent kinase activity. In comparison with the parent molecule, $(R)$-roscovitine, GV-58 has a $\sim 20$-fold less potent cyclin-dependent kinase antagonist effect, a $\sim 3$ - to 4 -fold more potent $\mathrm{Ca}^{2+}$ channel agonist effect, and $\sim 4$-fold higher efficacy as a $\mathrm{Ca}^{2+}$ channel agonist. We have further evaluated GV-58 in a passive transfer mouse model of Lambert-Eaton myasthenic syndrome and have shown that weakened Lambert-Eaton myasthenic syndromemodel neuromuscular synapses are significantly strengthened following exposure to GV-58. This new $\mathrm{Ca}^{2+}$ channel agonist has potential as a lead compound in the development of new therapeutic approaches to a variety of disorders that result in neuromuscular weakness.

\section{Introduction}

Lambert-Eaton myasthenic syndrome (LEMS) is an autoimmune disorder of the neuromuscular junction (NMJ) that is characterized by debilitating muscle weakness (Lambert et al., 1956). Although LEMS is often a paraneoplastic syndrome associated with small cell lung cancer, it can also be idiopathic (Titulaer et al., 2011b). This muscle weakness has been shown to be due to an auto-antibody-mediated removal of a fraction of presynaptic $\mathrm{P} / \mathrm{Q}$-type $\left(\mathrm{Ca}_{\mathrm{v}} 2.1\right) \mathrm{Ca}^{2+}$ channels, which provide the $\mathrm{Ca}^{2+}$ flux that normally triggers transmitter release at the mammalian NMJ (Katz et al., 1996). Despite a LEMSinduced compensatory expression of other calcium channel types, the overall effect is a decrease in the quantal content of

Received Sept. 28, 2012; revised May 21, 2013; accepted May 23, 2013.

Author contributions:T.B.T., P.W., and S.D.M. designed research;T.B.T.,W.M., M.L., G.V., M.F., A.G.-O.,P.W., and S.D.M. performed research; D.L. and S.W.R. contributed unpublished reagents/analytic tools; T.B.T., W.M., M.L., G.V., M.F., A.G.-O., P.W., and S.D.M. analyzed data; T.B.T., S.W.R., P.W., and S.D.M. wrote the paper.

This work was supported by the ARCS Foundation scholarship (to T.B.T.) and grants from the National Science Foundation (0844604 to S.D.M.), the National Institutes of Health (P50 CMLD Program GM067082 to P.W.), and the University of Pittsburgh Central Research Development Fund. We thank Nicholas DeStefino, Alexis Pilato, Cara Mazzarisi, Lu Li, Kathleen Schaefer, John Full, Michael Phillips, and Rachel Olszewski for early work on this project and assistance with some of the experiments. We thank Dr. Diane Lipscombe (Brown University) for providing the tsA201 cell line that stably expressed the $\mathrm{N}$-type $\mathrm{Ca}^{2+}$ channel.

The authors declare no competing financial interests.

Correspondence should be addressed to either of the following: Dr Stephen D. Meriney, Department of Neuroscience, A210 Langley Hall, University of Pittsburgh, Pittsburgh, PA 15260, E-mail: meriney@pitt.edu; or Dr Peter Wipf, Department of Chemistry, Parkman Avenue, CSC 1301, University of Pittsburgh, Pittsburgh, PA 15260, E-mail: pwipf@pitt.edu.

DOI:10.1523/JNEUROSCI.4629-12.2013

Copyright $\odot 2013$ the authors $\quad 0270-6474 / 13 / 3310559-09 \$ 15.00 / 0$ transmitter release from the NMJ (Vincent et al., 1989; Smith et al., 1995; Flink and Atchison, 2002). There is no cure for LEMS, and currently there are few symptomatic treatment options available. One of the most common therapeutic approaches is the use of the potassium channel blocker 3,4diaminopyridine (DAP), which indirectly increases presynaptic $\mathrm{Ca}^{2+}$ entry by broadening the action potential waveform, leading to an increase in transmitter release (Verschuuren et al., 2006; Oh et al., 2009; Wirtz et al., 2009). However, DAP is only partially effective in LEMS, and there are dose-limiting side-effects including paresthesia, gastric symptoms, insomnia, and less commonly, seizures (Verschuuren et al., 2006; Oh et al., 2009; Titulaer et al., 2011a). It would therefore be beneficial to have access to more treatment options. An alternative strategy would be to directly target the presynaptic $\mathrm{Ca}^{2+}$ channels involved in transmitter release.

$(R)$-roscovitine, a compound that was originally developed as a cyclin-dependent kinase (Cdk) inhibitor (Meijer et al., 1997), also displays direct $\mathrm{Ca}^{2+}$ channel agonist effects that are independent of Cdk effects (Yan et al., 2002; Buraei et al., 2005; Cho and Meriney, 2006). (R)-roscovitine slows the deactivation kinetics of $\mathrm{N}$ - and P/Q-type $\mathrm{Ca}^{2+}$ channels by increasing their mean open time (DeStefino et al., 2010), which leads to an increase in transmitter release at synapses (Yan et al., 2002; Cho and Meriney, 2006). Although $(R)$-roscovitine does target the $\mathrm{Ca}^{2+}$ channels involved in transmitter release at the NMJ, the potent $(R)$ roscovitine-mediated inhibition of Cdks presents a potential source of undesirable side-effects if used for the treatment of LEMS. Therefore, we set out to develop a novel analog of $(R)$ - 
roscovitine with both reduced Cdk antagonist effects and stronger $\mathrm{Ca}^{2+}$ channel agonist effects.

Using strategic medicinal chemistry modifications to the purine scaffold, we modified selected side chains present in $(R)$ roscovitine and characterized the resulting compounds by patchclamp electrophysiological measurements of calcium current, as well as in secondary kinase assays (Liang et al., 2012). Analogs that displayed reduced Cdk activity and strong agonist effects on calcium current were further evaluated using electrophysiological recordings of transmitter release from LEMS model mouse neuromuscular junctions. The most promising analog that emerged from these studies, GV-58, has $\sim 20$-fold lower potency as a Cdk antagonist, $\sim 3$ - to 4 -fold higher potency as a $\mathrm{Ca}^{2+}$ channel agonist, and $\sim 4$-fold higher efficacy as a $\mathrm{Ca}^{2+}$ channel agonist compared with the parent molecule, $(R)$-roscovitine.

\section{Materials and Methods}

Chemistry. (R)-roscovitine analogs were synthesized as reported previously (Liang et al., 2012) and used after they passed quality control analysis (liquid chromatography-mass spectrometry purity $>92 \%$ ).

Cell lines expressing $\mathrm{Ca}^{2+}$ channels. Initial screenings of $(R)$-roscovitine derivatives on N-type calcium channels were performed using a tsA-201 cell line that stably expressed the subunits of the $\mathrm{N}$-type $\mathrm{Ca}^{2+}$ channel splice variant present in mammalian brain and spinal cord: $\mathrm{Ca}_{\mathrm{v}} 2.2$ $\operatorname{rn} \alpha_{1 \mathrm{~B}-\mathrm{c}}\left(\mathrm{Ca}_{\mathrm{v}} 2.2 \mathrm{e}[24 \mathrm{a}, \Delta 31 \mathrm{a}]\right), \mathrm{Ca}_{\mathrm{v}} \beta_{3}$, and $\mathrm{Ca}_{\mathrm{v}} \alpha_{2} \delta_{1}$. For subsequent evaluation of effects on N-, P/Q-, or L-type channels, tsA-201 cells were transiently transfected with $\mathrm{Ca}_{v} 2.2, \mathrm{Ca}_{\mathrm{v}} 2.1$, or $\mathrm{Ca}_{\mathrm{v}} 1.3$, in combination with $\mathrm{Ca}_{\mathrm{v}} \beta_{3}$ and $\mathrm{Ca}_{\mathrm{v}} \alpha_{2} \delta_{1}$ (Addgene) using FuGENE 6 (Promega). All cells were maintained in DMEM supplemented with $10 \%$ fetal bovine serum. For the stable cell line expressing $\mathrm{N}$-type channels, $25 \mu \mathrm{g} / \mathrm{ml}$ zeocin, 5 $\mu \mathrm{g} / \mathrm{ml}$ blasticidin, and $25 \mu \mathrm{g} / \mathrm{ml}$ hygromycin were added as selection agents.

Whole-cell perforated patch-clamp recordings. To assess the effects of (R)-roscovitine analogs, whole-cell currents through $\mathrm{Ca}^{2+}$ channels were recorded using perforated patch methods as previously described (White et al., 1997; Yazejian et al., 1997; Cho and Meriney, 2006). Briefly, the pipette solution consisted of $70 \mathrm{~mm} \mathrm{Cs}_{2} \mathrm{SO}_{4}, 60 \mathrm{~mm} \mathrm{CsCl}, 1 \mathrm{~mm} \mathrm{MgCl}, 10$ mM 4-(2-hydroxyethyl)-1-piperazineethanesulfonic acid (HEPES) at pH 7.4. Cultured cells were bathed in a saline composed of $130 \mathrm{~mm}$ choline chloride $(\mathrm{ChCl}), 10 \mathrm{~mm}$ tetraethylammonium chloride (TEA-Cl), $2 \mathrm{~mm}$ $\mathrm{CaCl}_{2}, 1 \mathrm{~mm} \mathrm{MgCl}, 10 \mathrm{~mm}$ HEPES, at $\mathrm{pH}$ 7.4. Patch pipettes were fabricated from borosilicate glass and pulled to a resistance of $\sim 1 \mathrm{M} \Omega$. Before each experiment, a stock solution consisting of $3 \mathrm{mg}$ of amphotericin-B dissolved into $50 \mu \mathrm{l}$ of anhydrous DMSO was made. The tips of the pipettes were dipped into pipette solution that did not contain amphotericin-B for 5-10 s, and then backfilled with pipette solution that contained amphotericin-B ( $7 \mu \mathrm{l}$ amphotericin-B stock solution mixed into $500 \mu \mathrm{l}$ pipette solution, freshly made every hour). Using this approach, perforated patch access resistances were $7.41 \pm 1.75 \mathrm{M} \Omega$ (mean $\pm \mathrm{SD}, n=68$ ). Capacitive currents and passive membrane responses to voltage commands were subtracted from the data. Currents were amplified by an Axopatch 200B amplifier, filtered at $5 \mathrm{kHz}$, and digitized at $10 \mathrm{kHz}$ for subsequent analysis using pClamp 10 software (Molecular Devices). The liquid junction potential was subtracted during recordings. The tail current integral was measured before and after application of a compound, with the integral of each trace normalized to its peak. All experiments were performed at room temperature $\left(22^{\circ} \mathrm{C}\right)$. Stock solutions of $(R)$-roscovitine and the analog compounds were dissolved in DMSO at either 50 or $100 \mathrm{~mm}$ and stored at $-20^{\circ} \mathrm{C}$. $(R)$ roscovitine and the analog compounds were bath applied via a glass pipette in a $\sim 1.5 \mathrm{ml}$ static bath chamber during whole-cell recordings of calcium current. Control recordings performed with $0.1-1 \%$ DMSO alone added to the drug delivery pipette solution revealed no significant effects on whole-cell $\mathrm{Ca}^{2+}$ currents. All other salts and chemicals were obtained from Sigma-Aldrich.

Kinase screen of novel analogs. Each of the three novel analogs, along with the parent compound $(R)$-roscovitine, was tested for kinase activity using the EMD Millipore KinaseProfiler service. Each compound's kinase inhibitory activity was tested at three different concentrations $(0.2$, 2, and $20 \mu \mathrm{M}$ ) on five different kinases: $\mathrm{Cdk} 1$ cyclinB(h), cdk2 cycli$\mathrm{nA}(\mathrm{h})$, cdk5 p35(h), mitogen-activated protein kinase [MAPK1(h)], and myosin light-chain kinase $[\operatorname{MLCK}(\mathrm{h})]$. All kinases were tested in the presence of $10 \mu \mathrm{M}$ ATP.

LEMS passive transfer. To test GV-58 in a LEMS model NMJ, we used an established LEMS passive-transfer mouse model (Fukunaga et al., 1983; Lang et al., 1984; Fukuoka et al., 1987; Smith et al., 1995; Xu et al., 1998; Flink and Atchison, 2002). To perform this passive transfer of LEMS, mice were injected with the serum of patients diagnosed with LEMS. Collection of serum from LEMS patients was performed following the guidelines set forth by the University of Pittsburgh Institutional Review Board (IRB). Serum from patients $\mathrm{aBC} 2$ and $\mathrm{aCB}$ was collected using plasmapheresis. All other patient serum samples were obtained by collecting patient blood samples in serum separator tubes (BD Vacutainer Plus, BD Bioscience), which were spun down in a clinical centrifuge according to the manufacturer's specifications to isolate the serum. Each serum sample was tested for the presence of voltage-gated $\mathrm{Ca}^{2+}$ channel antibodies using a $\mathrm{Ca}^{2+}$ channel antibody radioimmune assay (Kronus RIA kit). Control serum was obtained from the University of Pittsburgh Medical Center blood bank. All serum, including control serum, was filtered with a $0.22 \mu \mathrm{m}$ filter before the injection protocol. Adult female CFW mice (2-3-months-old at beginning of passive transfer; weighing 25-32 g; Charles River Laboratories) were divided into two groups: one group that received LEMS serum, and a control group that received control serum. Mice received an intraperitoneal injection on day 1 of the treatment phase with $300 \mathrm{mg} / \mathrm{kg}$ cyclophosphamide to suppress immune responses, and were injected intraperitoneally once per day for 24-30 consecutive days with either $1.5 \mathrm{ml}$ serum from LEMS patients or $1.5 \mathrm{ml}$ control serum. In all cases, experimenters were blinded to the injection conditions.

Intracellular recordings at mouse NMJs. Following the passive transfer protocol, intracellular recordings to assess the LEMS-mediated deficit in transmitter release were made in an ex vivo nerve-muscle preparation. A thin upper arm muscle, the epitrochleoanconeus (ETA), was chosen for these recordings (Bradley et al., 1989; Rogozhin et al., 2008). This ex vivo nerve-muscle preparation was placed in a bath containing the following in mм: $118 \mathrm{NaCl}, 3.45 \mathrm{KCl}, 11$ dextrose, $26.2 \mathrm{NaHCO}_{3}, 1.7 \mathrm{NaH}_{2} \mathrm{PO}_{4}, 0.7$ $\mathrm{MgCl}_{2}, 2 \mathrm{CaCl}_{2}, \mathrm{pH}$ 7.4. The nerve was stimulated with a suction electrode and muscle contractions were blocked by exposure to $1 \mu \mathrm{M}$ $\mu$-conotoxin GIIIB (Alomone Labs). Microelectrode recordings were performed using $\sim 40-60 \mathrm{M} \Omega$ borosilicate electrodes filled with $3 \mathrm{M}$ potassium acetate. Spontaneous miniature synaptic events (mEPPs) were collected for 1-2 min in each muscle fiber, followed by single nerveevoked synaptic activity (10-30 EPPs) that was collected with an interstimulus interval of $5 \mathrm{~s}$. A train of 10 EPPs was also collected in each muscle fiber using an interstimulus interval of $20 \mathrm{~ms}$. To analyze the data, both the amplitudes and the areas under the waveforms (integral) were determined after correcting each digitized point in each trace for nonlinear summation (McLachlan and Martin, 1981). Data were collected using an Axoclamp 900A and digitized at $10 \mathrm{kHz}$ for subsequent analysis using pClamp 10 software (Molecular Devices).

Statistical analysis. Statistical analysis was performed using either GraphPad Prism 5 or Origin 7 (OriginLab). For the dose-response analyses on $\mathrm{Ca}^{2+}$ current, each concentration of the four different compounds was tested in 3-6 cells. For the dose-response analyses on kinase activity, each of the three concentrations was tested in duplicates $(n=2)$ for every compound except $(R)$-roscovitine, which was sent for kinase screening three times ( $n=6$ for each concentration). Dose-response curves for agonists were fit using the following equation: $y=y_{\max } /(1+$ $\left.\left(E C_{50} /[S]\right)^{n \mathrm{H}}\right)$, where $[S]$ is the agonist concentration and ${ }^{n \mathrm{H}}$ is the Hill coefficient. Antagonist inhibition curves were fit with the equation: $y=$ $y_{\max } /\left(1+\left([A] / I C_{50}\right)^{n \mathrm{H}}\right)$, where $[A]$ is the antagonist concentration and $n \mathrm{H}$ is the Hill coefficient. The fits were not weighted. Data are presented as mean \pm SEM unless otherwise noted. 


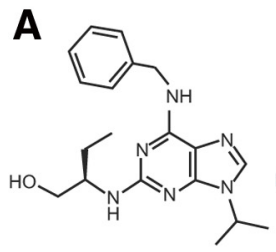

$(R)$-roscovitine

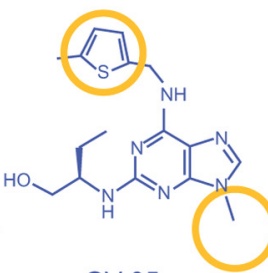

GV-05

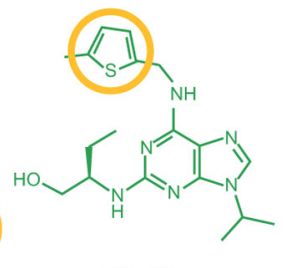

ML-50

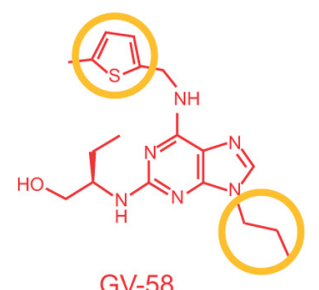

GV-58

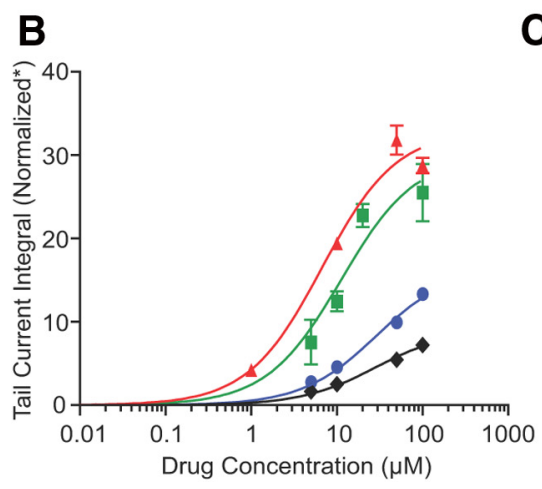

$\mathbf{C}_{V_{m}}$
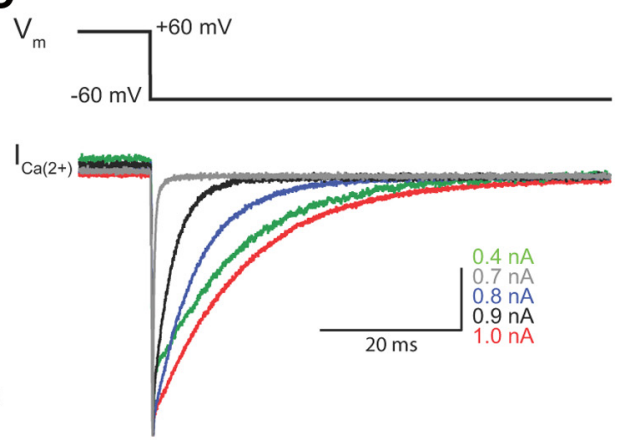

Figure 1. GV-58 shows increased $\mathrm{Ca}^{2+}$ channel activity compared with $(R)$-roscovitine. $A$, Structure of $(R)$-roscovitine and the three novel analogs with the strongest $\mathrm{Ca}^{2+}$ current agonist effects of the 24 analogs screened. Yellow circles indicate structural differences compared with (R)-roscovitine. $\boldsymbol{B}, \mathrm{Ca}^{2+}$ channel agonist activity dose-response curves for each of the compounds shown in $\boldsymbol{A}$. ${ }^{*}$ Each analog-modified tail current integral was normalized to its peak tail current and then divided by its respective control (untreated) tail current integral (also normalized to its respective peak current) to calculate the final value. C, Representative tail current traces are displayed for each of the compounds, along with a control tail current trace (gray trace). Each trace was obtained from a different cell and normalized at the peak for comparison. For $\boldsymbol{B}$ and $\boldsymbol{C}$, data are color-coded to match the colored structures in $\boldsymbol{A}$. Error bars indicate SEM.

\section{Results}

Effect of novel analogs of $(R)$-roscovitine on $\mathrm{Ca}^{2+}$ channel function

We previously reported the synthesis and structure of 24 novel analogs of roscovitine (Liang et al., 2012). Briefly, after an analysis of the available literature data for roscovitine analogs, we decided to primarily investigate replacements of the benzylamine and isopropyl side chains of the parent lead structure. The new compounds were generated using this strategy and probed for relative structure-activity relationships of Cdk versus calcium channel interactions (Liang et al., 2012). We initially screened the effect of these novel analogs of $(R)$-roscovitine on $\mathrm{Ca}^{2+}$ channel function using the whole-cell patch-clamp technique on tsA-201 cells expressing N-type $\left(\mathrm{Ca}_{\mathrm{v}} 2.2\right) \mathrm{Ca}^{2+}$ channels. Among the $24 \mathrm{com}-$ pounds synthesized and tested, three compounds in particular exhibited a strong agonist effect on the $\mathrm{Ca}^{2+}$ channel tail currents: GV-05, ML-50, and GV-58 (Fig. $1 A$ ). For comparison, the effect of $(R)$-roscovitine on $\mathrm{N}$-type tail currents was also determined. By measuring the tail current integrals (first normalizing each trace to its peak tail current amplitude and then normalizing to control integrals), the $\mathrm{EC}_{50}$ values of $(R)$-roscovitine, GV-05, ML-50, and GV-58 on N-type $\mathrm{Ca}^{2+}$ channels, which were reported previously (Liang et al., 2012), were determined and are listed in Table 1. The maximal fold-increase in the tail current integral relative to control was $\sim 8$-fold, $\sim 13$-fold, $\sim 25$-fold, and $\sim 32$-fold, when modified by $(R)$-roscovitine, GV-05, ML-50, and GV-58, respectively (Fig. $1 B, C$ ).

Effect of novel analogs of $(R)$-roscovitine on kinase activity In addition to seeking a compound with greater $\mathrm{Ca}^{2+}$ channel agonist activity than $(R)$-roscovitine, we also sought to synthesize a compound with reduced Cdk antagonist activity. We used a commercial kinase screen that tested the effect of these novel compounds and $(R)$ roscovitine on several kinases, including cdk1, cdk2, cdk5, MAPK1, and MLCK (Table 1). We were focused on reducing the antagonist activity of our novel analogs on these three Cdks because $(R)$ roscovitine is a potent inhibitor of all three (Meijer et al., 1997). The $\mathrm{IC}_{50}$ values for cdk1, cdk2, and cdk5 inhibition following exposure to $(R)$-roscovitine, GV05, ML-50, and GV-58 are shown in Table 1 IC $_{50}$ values for cdk 2 determined in our kinase screen were reported previously; Liang et al., 2012). Together, the data on $\mathrm{Ca}^{2+}$ channel and Cdk activity show that GV-58 displays the most desirable properties of the compounds we have synthesized and tested thus far, as it displays both a greatly increased $\mathrm{Ca}^{2+}$ channel agonist activity and a decreased Cdk antagonist activity compared with the parent molecule $(R)$-roscovitine (Table 1). For this reason, we chose GV-58 as our lead compound of interest and used it as the focus of the remainder of this study.

\section{Selectivity of GV-58 for N- and}

P/Q-type over L-type calcium channels

Using our lead compound with the best profile (GV-58), we then tested the agonist activity on P/Q-type channels $\left(\mathrm{Ca}_{\mathrm{v}} 2.1\right)$ and L-type $\left(\mathrm{Ca}_{\mathrm{v}} 1.3\right)$ channels using the same voltage-clamp protocol. We found that GV-58 had a very similar effect on P/Q-type channels as it did on $\mathrm{N}$-type channels $(8.81 \pm 1.07 \mu \mathrm{M}$ vs $7.21 \pm 0.86 \mu \mathrm{M}$ for P/Q- and $\mathrm{N}$-type channels, respectively). Additionally, GV-58 increased the P/Q-type channel tail current integral by $\sim 33$-fold compared with control, similar to its effect on $\mathrm{N}$-type channels ( $\sim 32$-fold). Finally, GV-58 had no agonist activity (up to $100 \mu \mathrm{M}$ ) on the L-type $\alpha$-subunit we tested $\left(\mathrm{Ca}_{\mathrm{v}} 1.3\right.$; Table 1$)$. In summary, GV-58 greatly improved upon $(R)$-roscovitine in terms of our properties of interest, with a $\sim 4$-fold increase in efficacy as an agonist for $\mathrm{N}$ - and $\mathrm{P} / \mathrm{Q}$-type $\mathrm{Ca}^{2+}$ channels, a $\sim 3$ - to 4 -fold increase in potency as an agonist for $\mathrm{N}$ - and $\mathrm{P} / \mathrm{Q}$-type $\mathrm{Ca}^{2+}$ channels, and a $\sim 20$-fold decrease in potency as a Cdk antagonist.

\section{Evaluating LEMS passive transfer model mice}

Having developed a novel $\mathrm{Ca}^{2+}$ channel analog with reduced $\mathrm{Cdk}$ activity and potent $\mathrm{Ca}^{2+}$ channel agonist activity, we then tested this analog in LEMS model mice. We used an established LEMS passive-transfer mouse model (Fukunaga et al., 1983; Lang et al., 1984; Fukuoka et al., 1987; Smith et al., 1995; Xu et al., 1998; Flink and Atchison, 2002), which involves daily injections of IgG or whole serum taken from patients who were diagnosed with LEMS. Using this approach, we tested the effects of whole serum injections from eight LEMS patients by measuring the quantal content in mouse ETA neuromuscular junctions following the passive transfer protocol (Fig. 2A), and comparing them to the quantal content of mice that underwent a passive transfer protocol with injections of control human serum. The clinical profile for each LEMS patient whose serum was studied is shown in Table 2. Several patients' serum caused no significant change in quantal content compared with control (Fig. 2A, black bars; 
Table 1. Comparison of $(R)$-roscovitine and novel analogs $\mathrm{EC}_{50} / \mathrm{IC}_{50}$ values (in $\left.\mu \mathrm{m}\right)$ for activity at calcium channels and kinases

\begin{tabular}{|c|c|c|c|c|c|c|c|c|}
\hline & $\mathrm{N}$-type $\left(\mathrm{Ca}_{\mathrm{v}} 2.2\right)$ & P/Q-type (Ca 2.1$)$ & L-type $\left(\mathrm{Ca}_{\mathrm{v}} 1.3\right)$ & Cdk1 & Cdk2 & Cdk5 & $\mathrm{MAPK}^{a}$ & $\mathrm{MLCK}^{a}$ \\
\hline (R)-roscovitine & $27.58 \pm 1.65$ & $120^{b}$ & $>100^{c}$ & $0.89 \pm 0.01$ & $0.15 \pm 0.004$ & $0.14 \pm 0.01$ & $>20$ & $>20$ \\
\hline GV-05 & $30.02 \pm 1.87$ & ND & ND & $10.46 \pm 2.77$ & $3.04 \pm 0.17$ & $2.81 \pm 0.91$ & $>20$ & $>20$ \\
\hline$M L-50$ & $11.29 \pm 1.48$ & ND & ND & $1.77 \pm 0.04$ & $0.26 \pm 0.0002$ & $0.27 \pm 0.01$ & $>20$ & $19.45 \pm 8.65$ \\
\hline GV-58 & $7.21 \pm 0.86$ & $8.81 \pm 1.07$ & $>100^{c}$ & $>20^{a}$ & $3.29 \pm 0.43$ & $3.03 \pm 0.32$ & $>20$ & $>20$ \\
\hline
\end{tabular}

${ }^{a} 20 \mu \mathrm{m}$ was the highest concentration used in kinase screens; therefore, an $\mathrm{IC}_{50}$ above $20 \mu \mathrm{m}$ could not be reliably determined.

${ }^{b}$ Literature $\mathrm{EC}_{50}$ value for (R)-roscovitine on P/Q-type $\mathrm{Ca}^{2+}$ channels taken from Buraei et al. (2007).

'No measureable agonist effect on L-type calcium channels up to $100 \mu \mathrm{m}$.

ND, Not determined.

$p>0.05$, one-way ANOVA with Tukey's post hoc test), whereas other patient's serum showed moderate to strong changes in quantal content compared with control (Fig. 2A, white bars; $p<0.05$, one-way ANOVA with Tukey's post hoc test). In addition to testing quantal content following our passive transfer protocol, we also performed an antibody radioimmune assay to determine the level of $\mathrm{Ca}^{2+}$ channel antibodies in each patient's serum (Fig. $2 B$ ). In general, those serum samples that significantly decreased quantal content had detectable levels of $\mathrm{Ca}^{2+}$ channel antibodies, although the level of these antibodies did not seem to correspond precisely to the level of quantal content decrease (Fig. 2A,B). Our aim was to choose a single patient's serum for repeated testing of our novel calcium channel agonist to have a consistent passive transfer effect in every mouse. For these studies, we chose the serum from patient aBC2 because the quantal content following the passive transfer with this serum $(40.5 \pm 9.9$; mean $\pm \mathrm{SD}, n=49$ terminals) was significantly reduced compared with control serum (102.4 \pm 25.1; mean $\pm \mathrm{SD}, n=41$ terminals, $p<0.05$, one-way ANOVA with Tukey's post hoc test; Fig. $2 A, C)$. EPP amplitude following passive transfer with aBC2 serum was also significantly smaller than EPP amplitude of NMJs injected with control serum $(14.15 \pm 0.64 \mathrm{mV}, n=49$ vs $34.61 \pm 1.37$ $\mathrm{mV}, n=41$ for aBC2 serum-treated NMJs and control serum-treated NMJs, respectively; $p<0.05$, Student's $t$ test), but mEPP amplitude was not significantly different between the two conditions (data not shown). Additionally, we had sufficient serum from patient $\mathrm{aBC} 2$ to perform all of the desired experiments. Therefore, all of the following experiments were performed using mice that underwent our passive transfer protocol using serum aBC2.

\section{GV-58 restores function in LEMS passive transfer NMJs}

Having developed a consistent LEMS passive transfer protocol, we tested the effect of our novel compound $(\mathrm{GV}-58)$ on action potential-evoked transmitter release from LEMS passive transfer mouse NMJs. EPP amplitude and quantal content were determined in the vehicle $(0.05-0.1 \%$ DMSO) before a $30 \mathrm{~min}$ incubation in $50 \mu \mathrm{M} \mathrm{GV-58,} \mathrm{which} \mathrm{was} \mathrm{then} \mathrm{followed} \mathrm{by} \mathrm{repeated} \mathrm{EPP}$
Table 2. Clinical data of each LEMS patient from whom serum was obtained and tested for this study

\begin{tabular}{lllcll}
\hline Patient & Age & $\begin{array}{l}\text { Age at } \\
\text { diagnosis }\end{array}$ & $\begin{array}{l}\text { CMAP } \\
\text { increment }(\%)\end{array}$ & $\begin{array}{l}\text { ANNA1 } \\
( \pm)\end{array}$ & $\begin{array}{l}\text { P/Q-type } \mathrm{Ca}^{2+} \\
\text { channel antibodies ( } \pm \text { ) }\end{array}$ \\
\hline PB & 62 & 52 & 500 & - & + \\
EB & 66 & 57 & 331 & - & + \\
PG & 71 & 68 & 1300 & - & + \\
JS & 56 & 42 & 109 & ND & - \\
aBC2 & 30 & 20 & $800-1600$ & + & + \\
SH & 61 & 55 & 78 & + & + \\
LE & 54 & 45 & 400 & - & + \\
aCB & 71 & 65 & 315 & - & + \\
\hline
\end{tabular}

Compound muscle action potential (CMAP) increment is a common diagnostic marker for LEMS and refers to the increase in CMAP size following a short exercise period ( $10 \mathrm{~s}$; 0 h et al., 2007).

ANNA1, Antineuronal nuclear antibody type I (also known as "anti-Hu"); ND, not determined. 
A
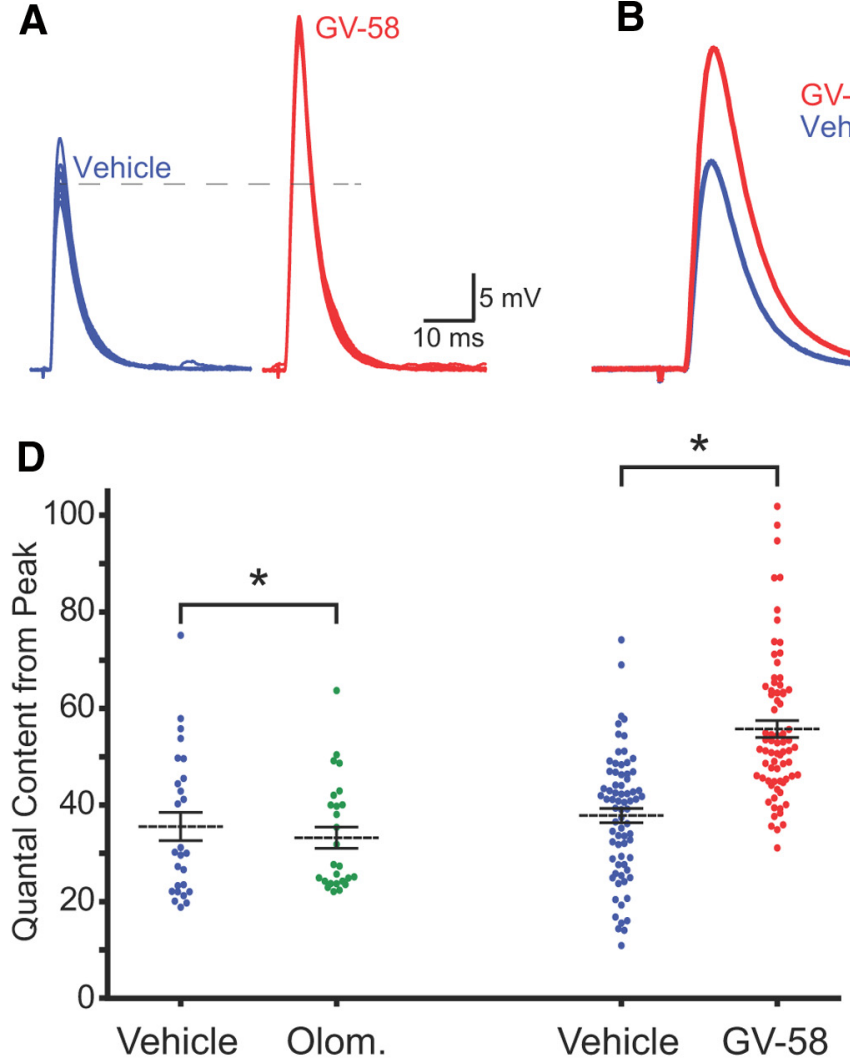

B

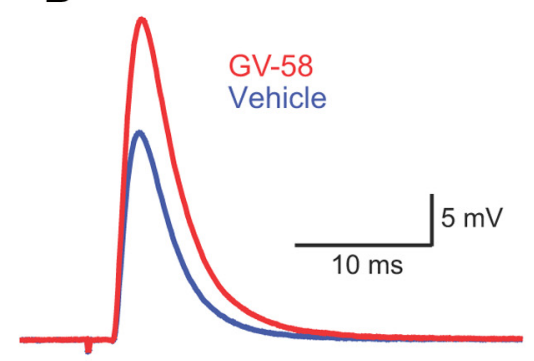

E
C
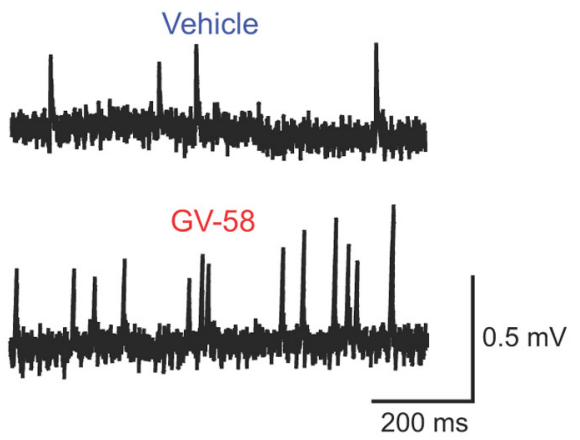

Figure 3. GV-58 increases transmitter release at LEMS model NMJs. $\boldsymbol{A}$, Sample traces (overlay of 10 traces in each example) show the increase in EPP amplitude following a 30 min incubation in $50 \mu \mathrm{M} \mathrm{GV}-58$ (red) relative to vehicle control (0.05-0.1\% DMS0; blue). Dashed line indicates the mean EPP amplitude in the example vehicle-treated LEMS NMJ. $\boldsymbol{B}$, Average of 10 traces from the same NMJ before (blue) and after (red) 30 min incubation in $50 \mu \mathrm{M} \mathrm{GV-58} \mathrm{show} \mathrm{a} \mathrm{GV-58-induced} \mathrm{widening} \mathrm{of} \mathrm{the} \mathrm{EPP} \mathrm{trace.} \mathrm{C,} \mathrm{Representative} \mathrm{mEPP} \mathrm{traces} \mathrm{from} \mathrm{the} \mathrm{same} \mathrm{NMJ} \mathrm{before} \mathrm{and} \mathrm{after} \mathrm{GV-58}$ application. $\boldsymbol{D}$, The quantal content determined by measuring the peak (peak EPP amplitude divided by the average peak mEPP amplitude) was slightly, but significantly smaller following $50 \mu \mathrm{M}$

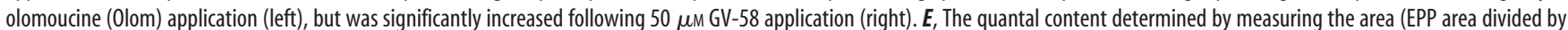
average $\mathrm{mEPP}$ area) was not significantly different following $50 \mu \mathrm{m}$ olomoucine application (left), but was significantly increased following GV-58 application (right). The scatter plots in both $\boldsymbol{D}$ and $\boldsymbol{E}$ represent the variability between individual synapses studied. Dashed line indicates the mean of each population. Error bars indicate SEM; ${ }^{*}$ indicates significance ( $\left.p<0.05\right)$.

amplitude and quantal content measurements from the same NMJs with the GV-58 still present in the bath. EPP amplitude was significantly increased from $13.00 \pm 0.56 \mathrm{mV}(n=73$ terminals $)$ in vehicle-treated aBC2 serum NMJs to $19.44 \pm 0.98 \mathrm{mV}(n=73$ terminals; $p<0.05$, Student's paired $t$ test) following application of $50 \mu \mathrm{M} \mathrm{GV}-58$ (Fig. $3 A, B$ ). The quantal content (determined by dividing the EPP peak amplitude by the mEPP peak amplitude) in the LEMS passive transfer vehicle control NMJs was $38.0 \pm$ 12.8 (mean $\pm \mathrm{SD}, n=73$ terminals), and was significantly increased after GV-58 exposure to $56.0 \pm 15.2$ (mean $\pm \mathrm{SD}, n=73$ terminals; $p<0.05$, Student's paired $t$ test; Fig. $3 D)$. Furthermore, when the quantal content was determined from the area (integral) under EPP and mEPP waveforms, the quantal content in the vehicle controls was $38.3 \pm 12.7$ (mean $\pm \mathrm{SD}, n=73$ terminals), and was significantly increased to $65.6 \pm 15.0$ (mean $\pm \mathrm{SD}, n=73$ terminals; $p<0.05$, Student's paired $t$ test; Fig. $3 E$ ) following GV-58 application. The difference between the compound's effect on quantal content when measuring peak ( $\sim 62 \%$ increase) compared with its effect on quantal content when measuring area ( $\sim 92 \%$ increase) suggests that there is a broadening of the EPP waveform caused by the action of GV-58 on $\mathrm{Ca}^{2+}$ channels (expected based on the GV-58-mediated slowing of $\mathrm{Ca}^{2+}$ current deactivation). To further explore this possibility, we measured both the full-width at half-maximum (FWHM) and the 90 to $10 \%$ decay time before and after GV-58 application. Figure $3 B$ shows an overlay of the average EPP am- plitudes in a sample NMJ before (blue) and after (red) GV-58 application. The FWHM increased significantly from $3.39 \pm 0.06$ $\mathrm{ms}$ in the vehicle controls ( $n=73$ terminals) to $3.90 \pm 0.07 \mathrm{~ms}$ following $50 \mu \mathrm{M} \mathrm{GV-58}$ application ( $n=73$ terminals; $p<0.05$, Student's paired $t$ test). Similarly, the 90 to $10 \%$ decay time increased from $5.84 \pm 0.12 \mathrm{~ms}$ in vehicle controls $(n=73$ terminals) to $6.79 \pm 0.11 \mathrm{~ms}$ following GV-58 application $(n=73$ terminals; $p<0.05$, Student's paired $t$ test). This indicates that the effect of GV-58 cannot fully be appreciated by only observing changes in peak EPP amplitude.

Previous reports have shown an increase in neurotransmitter release following pharmacological block or knock-out of cdk5 (Fu et al., 2005; Kim and Ryan, 2010). To ensure that the observed effect of GV-58 on transmitter release was not due to inhibition of Cdks, we tested the effect of olomoucine on transmitter release at LEMS passive transfer mouse NMJs. Olomoucine is a compound that is structurally related to $(R)$-roscovitine and has potent $\mathrm{Cdk}$ inhibitory activity (Vesely et al., 1994), but no $\mathrm{Ca}^{2+}$ channel activity (Buraei et al., 2005). Application of $50 \mu \mathrm{M}$ olomoucine caused a slight decrease in quantal content compared with vehicle controls when measuring quantal content from peak (35.7 \pm 15.0 , mean $\pm \mathrm{SD}, n=23$ vs $33.4 \pm 11.3$, mean $\pm \mathrm{SD}, n=23$, for vehicle controls and olomoucine, respectively; $n<0.05$, Student's paired $t$ test; Fig. $3 D$ ). The quantal content measured from area in vehicle controls $(36.1 \pm 14.3$, mean $\pm \mathrm{SD}, n=23)$ did not significantly change after application of olomoucine (34.6 \pm 
11.2 , mean $\pm \mathrm{SD}, n=23 ; p=0.16$, Student's paired $t$ test; Fig. $3 E$ ). Therefore, the effects of GV-58 on increasing action potential-evoked transmitter release at LEMS passive-transfer NMJs appear to be due to effects on $\mathrm{Ca}^{2+}$ channels rather than effects on Cdks.

In addition to analyzing the changes in quantal content and EPP kinetics, we also analyzed the effect of GV-58 on spontaneous transmitter release. Figure $3 C$ shows sample mEPP traces recorded in the vehicle control and following $50 \mu \mathrm{M} \mathrm{GV}-58$ application. The mEPP frequency was significantly increased from $3.27 \pm 0.15 \mathrm{~s}^{-1}$ $(n=73)$ in vehicle controls to $10.45 \pm$ $0.64 \mathrm{~s}^{-1}(n=73)$ following application of $50 \mu \mathrm{M} \mathrm{GV}-58(p<0.05$, Students paired $t$ test). Furthermore, the mEPP amplitude did not significantly change following addition of GV-58 (mean change in amplitude following GV-58 $=1.00 \pm 0.02$, $n=73 ; p=0.86$, Student's one sample $t$ test), consistent with a presynaptic locus for effects.

Finally, we determined the short-term plasticity characteristics of our LEMS model and the effect of GV-58 on these properties by eliciting trains of 10 stimuli at $50 \mathrm{~Hz}$ (Fig. 4). We first compared the short-term plasticity characteristics of our LEMS passive transfer model NMJs to those of NMJs taken from mice that received control serum injections. In the control serum condition, there is almost no facilitation, and by the $10^{\text {th }} \mathrm{EPP}$ in the train there is a depression to $\sim 66 \%$ of the first EPP. The trains of stimuli in the "aBC2" condition triggered EPPs that were generally erratic in size during any single train, but the overall average showed facilitation throughout the $50 \mathrm{~Hz}$ train, with a peak facilitation of $\sim 120 \%$ at EPP 4 and a small facilitation of $\sim 105 \%$ remaining at the final EPP in the train. When both conditions are normalized to the first EPP of the respective train, the control serum condition $(n=41)$ is significantly different from the aBC2 condition $(n=52)$ at each EPP in the train following the first $(p<$ 0.05 , Student's $t$ test; Fig. $4 A, B)$. We then compared the shortterm plasticity characteristics before $(0.05-0.1 \%$ DMSO vehicle) and after application of $50 \mu \mathrm{M} \mathrm{GV-58} \mathrm{in} \mathrm{our} \mathrm{LEMS} \mathrm{passive} \mathrm{trans-}$ fer model NMJs (Fig. 4C,D). The "Vehicle" condition shows facilitation throughout, with a facilitation of $\sim 113 \%$ remaining at the final EPP in the train. Following the application of $50 \mu \mathrm{M}$ GV-58 in the same NMJs, there was a slight facilitation followed by depression to $\sim 94 \%$ at the final EPP in the train. Furthermore, the "GV-58" condition was significantly different from the Vehicle condition at every EPP following the first when both conditions are normalized to the first EPP of the train $(p<0.05$, Student's paired $t$ test; Fig. $4 C, D)$.

\section{Discussion}

We have shown that directly targeting presynaptic $\mathrm{Ca}^{2+}$ channels using a novel agonist can partially restore the deficiency of trans-
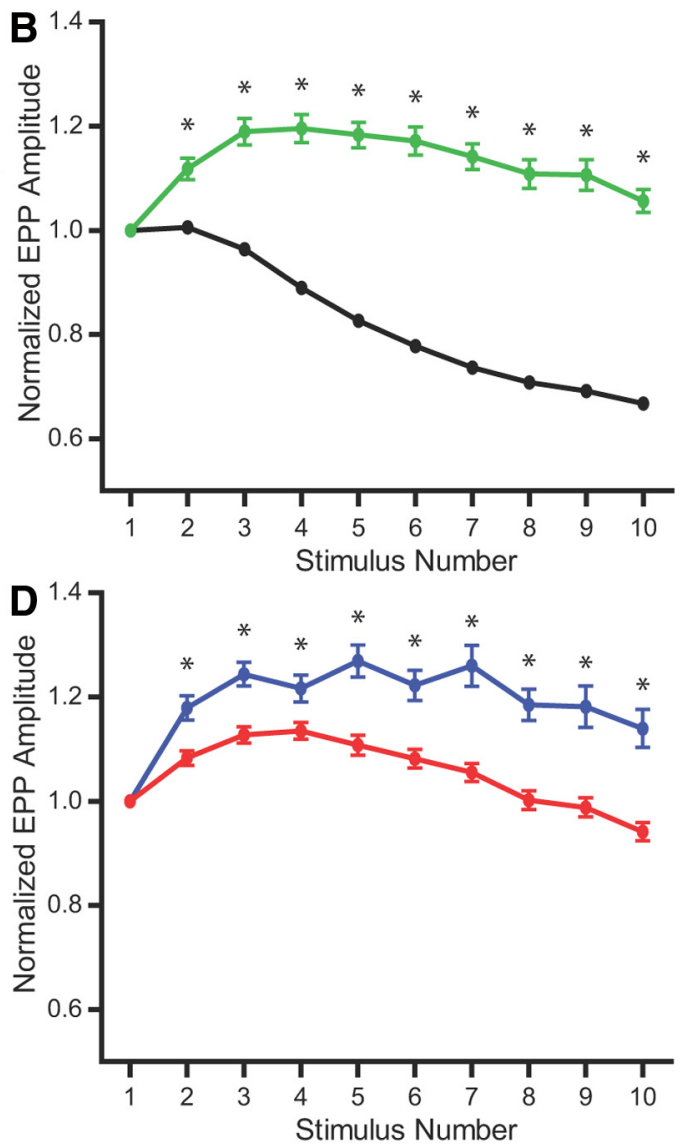

Figure 4. Short-term plasticity during trains of stimuli. $A$, Representative EPPs evoked by $50 \mathrm{~Hz}$ stimuli recorded from terminals in control serum-injected mice (black) and $\mathrm{aBC}$ LEMS serum-injected mice (green). $\boldsymbol{B}$, Plot of the average $50 \mathrm{~Hz}$ train data normalized to the amplitude of the first EPP of the train for the two conditions shown in $\boldsymbol{A}$. $\boldsymbol{C}$, Representative $50 \mathrm{~Hz}$ trains for aBC2 列

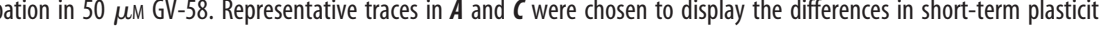
tions. Asterisks in $\boldsymbol{B}$ and $\boldsymbol{D}$ indicate a significant difference between the two normalized EPP amplitudes below each asterisk as determined by a Student's $t$ test in $\boldsymbol{B}$ or a Student's paired $t$ test in $\boldsymbol{D}$. Error bars indicate SEM ; ${ }^{*}$ indicates significance $(p<0.05)$.

mitter release in a LEMS passive-transfer mouse model NMJ. By synthesizing and screening multiple analogs of $(R)$-roscovitine, we identified a compound $(\mathrm{GV}-58)$ that has both a reduced $\mathrm{Cdk}$ antagonist activity and an increased $\mathrm{Ca}^{2+}$ channel agonist activity. Although further testing will be required to evaluate $\mathrm{Ca}^{2+}$ channel agonists as viable treatment options for patients with LEMS, our work suggests that directly targeting presynaptic $\mathrm{Ca}^{2+}$ channels represents a new therapeutic paradigm for patients with LEMS.

\section{GV-58 effects on transmitter release}

Our novel $\mathrm{Ca}^{2+}$ channel agonist GV-58 increases the amount of $\mathrm{Ca}^{2+}$ influx through channels that open during an action potential, which in turn leads to an increase in the amount of transmitter released (Fig. 3). This effect is not due to inhibition of Cdks, as the potent Cdk inhibitor olomoucine had no agonist effect on transmitter release (Fig. $3 D, E$ ). When determining how such a $\mathrm{Ca}^{2+}$ channel agonist would increase transmitter release at the mammalian NMJ, it is useful to consider the calcium-dependent mechanisms that normally regulate release at this synapse. The adult mouse NMJ has been shown to contain $\sim 850$ very small active zones (Ruiz et al., 2011; Chen et al., 2012), each of which 
contains approximately two docked synaptic vesicles (Nagwaney et al., 2009). Because the entire adult mouse ETA neuromuscular synapse releases $\sim 100$ vesicles normally following each action potential stimulus (Fig. 2), the probability of release from each active zone is $\sim 12 \%$ (assuming a homogeneous release probability across all active zones during low-frequency stimulation; Gaffield et al., 2009, although a heterogeneous distribution is also possible; Wyatt and Balice-Gordon, 2008). There are an unknown number of $\mathrm{Ca}^{2+}$ channels positioned with mouse NMJ active zones, but if there are relatively few present, and if they have a low probability of opening as has been shown at the frog NMJ (Luo et al., 2011), this may contribute significantly to the low probability of release from each active zone. Furthermore, the coupling between calcium channel opening and vesicle fusion in these active zones may also be very low (similar mechanisms appear to control release at the frog NMJ; Wachman et al., 2004; Luo et al., 2011; Tarr et al., 2013). Under these conditions, a calcium channel agonist like GV-58 would be expected to increase the flux through a subset of open channels, increasing the probability of vesicle fusion at these sites.

Interestingly, some NMJs show more than a threefold increase in transmitter release after exposure to GV-58, whereas others show a very small effect (Fig. $3 D, E$, scatter plots). There are several potential sources of variability in GV-58 effects on quantal content. First, during our relatively short (30-60 min) exposure, there may have been variable connective tissue barriers to diffusion, which may have resulted in different concentrations of GV-58 affecting particular NMJs within the muscle. It is also possible that the mix of calcium channels at LEMS model synapses is variable when compared between NMJs (even in the same muscle). Compensatory changes in $\mathrm{Ca}^{2+}$ channel expression have been reported to include an upregulation of $\mathrm{L}$-type $\mathrm{Ca}^{2+}$ channel expression at the NMJ that might contribute to the triggering of release at these disease model synapses (Flink and Atchison, 2002), but L-type channels would not be sensitive to modulation by GV-58 (see Table 1).

We have also shown that GV-58 partially restores normal short-term plasticity characteristics in LEMS model mouse NMJs (Fig. 4). One interesting observation is the lack of facilitation in the $50 \mathrm{~Hz}$ train in control serum NMJs compared with the large facilitation present in the $50 \mathrm{~Hz}$ train in LEMS serum-treated NMJs. If many $\mathrm{Ca}^{2+}$ channels contribute to the release of a single vesicle within each active zone, as has been shown in multiple CNS synapses (Eggermann et al., 2012; Tarr et al., 2013), then the large facilitation in the LEMS serum-treated NMJs would be caused by a smaller total intracellular $\mathrm{Ca}^{2+}$ flux through fewer calcium channels at each active zone. GV-58 would then compensate by increasing the $\mathrm{Ca}^{2+}$ influx through the remaining $\mathrm{Ca}^{2+}$ channels at the active zone. If, however, the mouse NMJ functions as has been reported at the frog NMJ, there may be an approximately one-to-one relationship between $\mathrm{Ca}^{2+}$ channel opening and vesicle fusion (Luo et al., 2011; Tarr et al., 2013). Under these conditions at the small, isolated active zones present at the mouse NMJ, an explanation for the increase in facilitation observed in the LEMS serum-treated NMJs is less straightforward. In this scenario, if the opening of one $\mathrm{Ca}^{2+}$ channel normally contributes to the release of one vesicle $\left(\mathrm{Ca}^{2+}\right.$ channel - release site cooperativity $=1$ ), then simply removing $\mathrm{Ca}^{2+}$ channels (as a result of LEMS) should only reduce quantal content without affecting shortterm plasticity because each release site that lost a calcium channel would simply drop out, with no change in the calcium flux at release sites that had a calcium channel opening. On the other hand, if there is a compensatory expression of other types of $\mathrm{Ca}^{2+}$ channels in
LEMS NMJs (Flink and Atchison, 2002), this may result in the insertion of $\mathrm{Ca}^{2+}$ channels into sites further away from the vesicle and its release machinery (Urbano et al., 2003). This could lead to a $\mathrm{Ca}^{2+}$ channel-release site coupling such that it might be required that more than one open $\mathrm{Ca}^{2+}$ channel provide the flux that is necessary for the release of a single vesicle. Under these conditions, one would predict an increased facilitation during a $50 \mathrm{~Hz}$ train compared with control. GV-58 would then reverse this by increasing the $\mathrm{Ca}^{2+}$ influx through each channel, thus increasing the likelihood that the flux through a single channel could trigger the release of a synaptic vesicle. Last, it is also possible that active zone structure and organization is disrupted in the LEMS passive transfer NMJ (Fukunaga et al., 1983). Disruption of active zone structure and organization could alter the normally one-to-one $\mathrm{Ca}^{2+}$ channel-to-vesicle coupling, thus accounting for both the facilitation seen in the LEMS serumtreated NMJs and the partial restoration of short-term plasticity characteristics by GV-58 as described above. LEMS could induce active zone disorganization in this scenario by disrupting the interactions between $\mathrm{Ca}^{2+}$ channels and active zone proteins following the autoimmune-mediated removal of $\mathrm{Ca}^{2+}$ channels. For example, previous work has shown that preventing the interaction between $\mathrm{Ca}^{2+}$ channels and the active zone protein laminin $\beta 2$ induces active zone disorganization similar to that seen in LEMS NMJs (Fukunaga et al., 1983; Nishimune et al., 2004; Chen et al., 2011).

\section{New calcium channel agonists as potential therapeutics for LEMS patients}

There are few symptomatic treatment options for LEMS, and those that are available can sometimes be associated with unwanted side effects (Verschuuren et al., 2006; Oh et al., 2009; Titulaer et al., 2011a). The currently recommended symptomatic treatment option (DAP) works to increase transmitter release by broadening the action potential waveform to increase $\mathrm{Ca}^{2+}$ influx (Verschuuren et al., 2006). Directly targeting the $\mathrm{Ca}^{2+}$ channels involved in transmitter release at the NMJ could represent an alternative treatment option for LEMS patients. Additionally, a $\mathrm{Ca}^{2+}$ channel agonist might be used in combination with DAP to exert synergistic effects on transmitter release when both are applied at concentrations that are lower than what is required for effects when either is given alone.

Before this study, the only known compound with agonist effects on the $\mathrm{Ca}^{2+}$ channel subtypes involved with transmitter release at the NMJ was $(R)$-roscovitine (Yan et al., 2002; Buraei et al., 2005; Cho and Meriney, 2006). Our chemical modifications of $(R)$-roscovitine have led to the generation of GV-58, which represents a promising lead structure in the development of selective calcium channel agonists. Additional chemical modifications to further reduce Cdk activity would be useful, but given that these compounds compete with ATP for binding to Cdks (De Azevedo et al., 1997), the high cellular ATP concentrations (in the 1-10 mM range; Maechler et al., 1998; Kennedy et al., 1999) are expected to outcompete compounds that bind with affinities in the $\mu \mathrm{M}$ range.

In addition to the possibility of treating the muscle weakness associated with LEMS, a direct $\mathrm{Ca}^{2+}$ channel agonist could also serve as a treatment option for other neuromuscular diseases characterized by muscle weakness. In particular, $\mathrm{a} \mathrm{Ca}^{2+}$ channel agonist would be expected to provide symptomatic relief for some of the congenital myasthenic syndromes (Schara et al., 2012), and perhaps myasthenia gravis caused by muscle-specific kinase autoantibodies (Mori et al., 2012; Morsch et al., 2013). The effects of GV-58 on animal models of other neuromuscular diseases remain to be examined. Of course, before treatment options 
can be considered further, off-target effects, toxicity, and bloodbrain barrier penetrance will also need to be examined.

\section{New calcium channel agonists as experimental tools}

Independent of its therapeutic potential for treatment of diseases characterized by neuromuscular weakness, a selective and potent $\mathrm{Ca}^{2+}$ channel agonist of the P/Q- and N-type $\mathrm{Ca}^{2+}$ channels would serve as an important experimental tool for studying the basic properties of these $\mathrm{Ca}^{2+}$ channel subtypes. Just as the L-type $\mathrm{Ca}^{2+}$ channel agonists BayK 8644 and FPL64176 were important in studies of L-type channel gating, conductance, and kinetics (Hess et al., 1984; Zheng et al., 1991; Church and Stanley, 1996; Tavalin et al., 2004), an agonist of the P/Q- and N-type channels would be equally useful in the study of their properties. Furthermore, GV-58 may serve as a useful probe molecule in studies of the calcium control of chemical transmitter release. Even though $(R)$-roscovitine is an agonist of the P/Q- and N-type channel subtypes, our novel compound GV-58 is more selective and potent than $(R)$-roscovitine, and thus likely to be more effective for studies on basic P/Q- and $\mathrm{N}$-type $\mathrm{Ca}^{2+}$ channel function.

\section{References}

Bradley SA, Lyons PR, Slater CR (1989) The epitrochleoanconeus muscles (ETA) of the mouse: a useful muscle for the study of motor innervation. J Physiol 415:3P.

Buraei Z, Anghelescu M, Elmslie KS (2005) Slowed N-type calcium channel (CaV2.2) deactivation by the cyclin-dependent kinase inhibitor roscovitine. Biophys J 89:1681-1691. CrossRef Medline

Buraei Z, Schofield G, Elmslie KS (2007) Roscovitine differentially affects $\mathrm{CaV} 2$ and $\mathrm{Kv}$ channels by binding to the open state. Neuropharmacology 52:883-894. CrossRef Medline

Chen J, Billings SE, Nishimune H (2011) Calcium channels link the musclederived synapse organizer laminin $\beta 2$ to Bassoon and CAST/Erc2 to organize presynaptic active zones. J Neurosci 31:512-525. CrossRef Medline

Chen J, Mizushige T, Nishimune H (2012) Active zone density is conserved during synaptic growth but impaired in aged mice. J Comp Neurol 520: 434-452. CrossRef Medline

Cho S, Meriney SD (2006) The effects of presynaptic calcium channel modulation by roscovitine on transmitter release at the adult frog neuromuscular junction. Eur J Neurosci 23:3200-3208. CrossRef Medline

Church PJ, Stanley EF (1996) Single L-type calcium channel conductance with physiological levels of calcium in chick ciliary ganglion neurons. J Physiol 496:59-68. Medline

De Azevedo WF, Leclerc S, Meijer L, Havlicek L, Strnad M, Kim SH (1997) Inhibition of cyclin-dependent kinases by purine analogues: crystal structure of human cdk2 complexed with roscovitine. Eur J Biochem 243:518526. CrossRef Medline

DeStefino NR, Pilato AA, Dittrich M, Cherry SV, Cho S, Stiles JR, Meriney SD (2010) (R)-roscovitine prolongs the mean open time of unitary N-type calcium channel currents. Neuroscience 167:838-849. CrossRef Medline

Eggermann E, Bucurenciu I, Goswami SP, Jonas P (2012) Nanodomain coupling between $\mathrm{Ca}(2)$ channels and sensors of exocytosis at fast mammalian synapses. Nat Rev Neurosci 13:7-21. CrossRef Medline

Flink MT, Atchison WD (2002) Passive transfer of Lambert-Eaton syndrome to mice induces dihydropyridine sensitivity of neuromuscular transmission. J Physiol 543:567-576. CrossRef Medline

Fu AK, Ip FC, Fu WY, Cheung J, Wang JH, Yung WH, Ip NY (2005) Aberrant motor axon projection, acetylcholine receptor clustering, and neurotransmission in cyclin-dependent kinase 5 null mice. Proc Natl Acad Sci U S A 102:15224-15229. CrossRef Medline

Fukunaga H, Engel AG, Lang B, Newsom-Davis J, Vincent A (1983) Passive transfer of Lambert-Eaton myasthenic syndrome with IgG from man to mouse depletes the presynaptic membrane active zones. Proc Natl Acad Sci U S A 80:7636-7640. CrossRef Medline

Fukuoka T, Engel AG, Lang B, Newsom-Davis J, Vincent A (1987) Lambert-Eaton myasthenic syndrome: II. Immunoelectron microscopy localization of IgG at the mouse motor end-plate. Ann Neurol 22:200-211. CrossRef Medline

Gaffield MA, Tabares L, Betz WJ (2009) The spatial pattern of exocytosis and postexocytic mobility of synaptopHluorin in mouse motor nerve terminals. J Physiol 587:1187-1200. CrossRef Medline

Hess P, Lansman JB, Tsien RW (1984) Different modes of Ca channel gating behaviour favoured by dihydropyridine Ca agonists and antagonists. Nature 311:538-544. CrossRef Medline

Katz E, Ferro PA, Weisz G, Uchitel OD (1996) Calcium channels involved in synaptic transmission at the mature and regenerating mouse neuromuscular junction. J Physiol 497:687-697. Medline

Kennedy HJ, Pouli AE, Ainscow EK, Jouaville LS, Rizzuto R, Rutter GA (1999) Glucose generates subplasma membrane ATP microdomains in single islet beta-cells: potential role for strategically located mitochondria. J Biol Chem 274:13281-13291. CrossRef Medline

Kim SH, Ryan TA (2010) CDK5 serves as a major control point in neurotransmitter release. Neuron 67:797-809. CrossRef Medline

Lambert EH, Eaton LM, Rooke ED (1956) Defect of neuromuscular conduction associated with malignant neoplasm. Am J Physiol 187:612-613.

Lang B, Molenaar PC, Newsom-Davis J, Vincent A (1984) Passive transfer of Lambert-Eaton myasthenic syndrome in mice: decreased rates of resting and evoked release of acetylcholine from skeletal muscle. J Neurochem 42:658-662. CrossRef Medline

Liang M, Tarr TB, Bravo-Altamirano K, Valdomir G, Rensch G, Swanson L, DeStefino NR, Mazzarisi CM, Olszewski RA, Wilson GM, Meriney SD, Wipf P (2012) Synthesis and biological evaluation of a selective N- and P/Q-type calcium channel agonist. ACS Med Chem Lett 3:985-990. CrossRef

Luo F, Dittrich M, Stiles JR, Meriney SD (2011) Single-pixel optical fluctuation analysis of calcium channel function in active zones of motor nerve terminals. J Neurosci 31:11268-11281. CrossRef Medline

Maechler P, Wang H, Wollheim CB (1998) Continuous monitoring of ATP levels in living insulin secreting cells expressing cytosolic firefly luciferase. FEBS Lett 422:328-332. CrossRef Medline

McLachlan EM, Martin AR (1981) Non-linear summation of end-plate potentials in the frog and mouse. J Physiol 311:307-324. Medline

Meijer L, Borgne A, Mulner O, Chong JP, Blow JJ, Inagaki N, Inagaki M, Delcros JG, Moulinoux JP (1997) Biochemical and cellular effects of roscovitine, a potent and selective inhibitor of the cyclin-dependent kinases cdc2, cdk2 and cdk5. Eur J Biochem 243:527-536. CrossRef Medline

Mori S, Kishi M, Kubo S, Akiyoshi T, Yamada S, Miyazaki T, Konishi T, Maruyama N, Shigemoto K (2012) 3,4-Diaminopyridine improves neuromuscular transmission in a MuSK antibody-induced mouse model of myasthenia gravis. J Neuroimmunol 245:75-78. CrossRef Medline

Morsch M, Reddel SW, Ghazanfari N, Toyka KV, Phillips WD (2013) Pyridostigmine but not 3,4-diaminopyridine exacerbates ACh receptor loss and myasthenia induced in mice by muscle-specific kinase autoantibody. J Physiol 591:2747-2762. CrossRef Medline

Nagwaney S, Harlow ML, Jung JH, Szule JA, Ress D, Xu J, Marshall RM, McMahan UJ (2009) Macromolecular connections of active zone material to docked synaptic vesicles and presynaptic membrane at neuromuscular junctions of mouse. J Comp Neurol 513:457-468. CrossRef Medline

Nishimune H, Sanes JR, Carlson SS (2004) A synaptic laminin-calcium channel interaction organizes active zones in motor nerve terminals. Nature 432:580-587. CrossRef Medline

Oh SJ, Hatanaka Y, Claussen GC, Sher E (2007) Electrophysiological differences in seropositive and seronegative Lambert-Eaton myasthenic syndrome. Muscle Nerve 35:178-183. CrossRef Medline

Oh SJ, Claussen GG, Hatanaka Y, Morgan MB (2009) 3,4-Diaminopyridine is more effective than placebo in a randomized, double-blind, cross-over drug study in LEMS. Muscle Nerve 40:795-800. CrossRef Medline

Rogozhin AA, Pang KK, Bukharaeva E, Young C, Slater CR (2008) Recovery of mouse neuromuscular junctions from single and repeated injections of botulinum neurotoxin A. J Physiol 586:3163-3182. CrossRef Medline

Ruiz R, Cano R, Casañas JJ, Gaffield MA, Betz WJ, Tabares L (2011) Active zones and the readily releasable pool of synaptic vesicles at the neuromuscular junction of the mouse. J Neurosci 31:2000-2008. CrossRef Medline

Schara U, Della Marina A, Abicht A (2012) Congenital myasthenic syndromes: current diagnostic and therapeutic approaches. Neuropediatrics 43:184-193. CrossRef Medline

Smith DO, Conklin MW, Jensen PJ, Atchison WD (1995) Decreased calcium currents in motor nerve terminals of mice with Lambert-Eaton myasthenic syndrome. J Physiol 487:115-123. Medline

Tarr TB, Dittrich M, Meriney SD (2013) Are unreliable release mechanisms 
conserved from NMJ to CNS? Trends Neurosci 36:14-22. CrossRef Medline

Tavalin SJ, Shepherd D, Cloues RK, Bowden SE, Marrion NV (2004) Modulation of single channels underlying hippocampal L-type current enhancement by agonists depends on the permeant ion. J Neurophysiol 92:824-837. CrossRef Medline

Titulaer MJ, Lang B, Verschuuren JJ (2011a) Lambert-Eaton myasthenic syndrome: from clinical characteristics to therapeutic strategies. Lancet Neurol 10:1098-1107. CrossRef Medline

Titulaer MJ, Maddison P, Sont JK, Wirtz PW, Hilton-Jones D, Klooster R, Willcox N, Potman M, Sillevis Smitt PA, Kuks JB, Roep BO, Vincent A, van der Maarel SM, van Dijk JG, Lang B, Verschuuren JJ (2011b) Clinical Dutch-English Lambert-Eaton myasthenic syndrome (LEMS) tumor association prediction score accurately predicts small-cell lung cancer in the LEMS. J Clin Oncol 29:902-908. CrossRef Medline

Urbano FJ, Piedras-Rentería ES, Jun K, Shin HS, Uchitel OD, Tsien RW (2003) Altered properties of quantal neurotransmitter release at endplates of mice lacking P/Q-type $\mathrm{Ca}^{2+}$ channels. Proc Natl Acad Sci U S A 100:3491-3496. CrossRef Medline

Verschuuren JJ, Wirtz PW, Titulaer MJ, Willems LN, van Gerven J (2006) Available treatment options for the management of Lambert-Eaton myasthenic syndrome. Expert Opin Pharmacother 7:1323-1336. CrossRef Medline

Veseleý J, Havlicek L, Strnad M, Blow JJ, Donella-Deana A, Pinna L, Letham DS, Kato J, Detivaud L, Leclerc S, Meijer L (1994) Inhibition of cyclindependent kinases by purine analogues. Eur J Biochem 224:771-786. CrossRef Medline

Vincent A, Lang B, Newsom-Davis J (1989) Autoimmunity to the voltagegated calcium channel underlies the Lambert-Eaton myasthenic syndrome, a paraneoplastic disorder. Trends Neurosci 12:496-502. CrossRef Medline
Wachman ES, Poage RE, Stiles JR, Farkas DL, Meriney SD (2004) Spatial distribution of calcium entry evoked by single action potentials within the presynaptic active zone. J Neurosci 24:2877-2885. CrossRef Medline

White MG, Crumling MA, Meriney SD (1997) Developmental changes in calcium current pharmacology and somatostatin inhibition in chick parasympathetic neurons. J Neurosci 17:6302-6313. Medline

Wirtz PW, Verschuuren JJ, van Dijk JG, de Kam ML, Schoemaker RC, van Hasselt JG, Titulaer MJ, Tjaden UR, den Hartigh J, van Gerven JM (2009) Efficacy of 3,4-diaminopyridine and pyridostigmine in the treatment of Lambert-Eaton myasthenic syndrome: a randomized, double-blind, placebo-controlled, crossover study. Clin Pharmacol Ther 86:44-48. CrossRef Medline

Wyatt RM, Balice-Gordon RJ (2008) Heterogeneity in synaptic vesicle release at neuromuscular synapses of mice expressing synaptopHluorin. J Neurosci 28:325-335. CrossRef Medline

Xu YF, Hewett SJ, Atchison WD (1998) Passive transfer of Lambert-Eaton myasthenic syndrome induces dihydropyridine sensitivity of ICa in mouse motor nerve terminals. J Neurophysiol 80:1056-1069. Medline

Yan Z, Chi P, Bibb JA, Ryan TA, Greengard P (2002) Roscovitine: a novel regulator of $\mathrm{P} / \mathrm{Q}$-type calcium channels and transmitter release in central neurons. J Physiol 540:761-770. CrossRef Medline

Yazejian B, DiGregorio DA, Vergara JL, Poage RE, Meriney SD, Grinnell AD (1997) Direct measurements of presynaptic calcium and calciumactivated potassium currents regulating neurotransmitter release at cultured Xenopus nerve-muscle synapses. J Neurosci 17:2990-3001. Medline

Zheng W, Rampe D, Triggle DJ (1991) Pharmacological, radioligand binding, and electrophysiological characteristics of FPL 64176, a novel nondihydropyridine $\mathrm{Ca}^{2+}$ channel activator, in cardiac and vascular preparations. Mol Pharmacol 40:734-741. Medline 